\title{
PENERAPAN TEKNOLOGI PENJERNIH AIR PADA KELOMPOK USAHA TAHU DALAM UPAYA PENINGKATAN KUALITAS TAHU DI KOTA BENGKULU
}

\section{WATER TREATMENT TECHNOLOGY APPLICATION ON TOFU INDUSTRY TO INCREASE TOFU QUALITY IN BENGKULU CITY}

\author{
Oleh: \\ Irnanda Priyadi, Faisal Hadi, Khairul Amri \\ Fakultas Teknik, Universitas Bengkulu \\ Email: Irnanda_P@unib.ac.id
}

\begin{abstract}
Clean water is one of the important components needed in the process of making tofu. Water sources in the city of Bengkulu, whether managed by PDAM or from dug wells with a depth of less than ten meters, have poor water quality. This will affect to the quality of tofu produced. And wiil be affect to the tofu bussiness development at Bengkulu city in the future time. One alternative solution to solve this problem was designed water purifier using solar cell technology with microcontroller to overcome the clean and hygienic water supply more economical. Specific targets to be achieved in this activity are patents products with affordable raw materials and prices. The results of the manufacturing of the purification module show the LCD reading of the water quality parameters used for the preparation of tofu prior to treatment using TDS sensor detection and $\mathrm{pH}$ sensor are 5,885 and 8,320. While the LCD reading after the treatment using TDS sensor detection and $p H$ sensors are 4,901 and 7,763. Further laboratory test results on the performance of water purification module for the manufacture of tofu application showed an increase of TSS level. The next result, amount of the total Coli content is 551/100mL at the before and become 28/100mL at the after. Meanwhile, the conductivity is being increased from 459 at the before and become 469 at the after.
\end{abstract}

Keywords: tofu business group, water purifier, solar cell technology, microcontroller.

\section{PENDAHULUAN}

Tahu merupakan salah satu jenis makanan tradisonal yang digemari hampir seluruh lapisan masyarakat di Indonesia. Selain mengandung nilai gizi yang tinggi, harga jual tahu juga relatif terjangkau. Dalam proses pembuatan tahu, setiap tahapan umumnya menggunakan air bersih sebagai bahan pembantu dalam jumlah yang relatif banyak. Menurut Nuraida (1985), untuk setiap $1 \mathrm{~kg}$ bahan baku kedelai dibutuhkan rata-rata 45 liter air. Sehingga kebersihan (sanitasi) air menjadi permasalahan yang besar dalam menentukan mutu tahu (Rahmawati, 2013).

Sumber air untuk air minum, mandi dan kebutuhan sehari-hari masyarakat Kota Bengkulu sebagian besar berasal dari air sumur jenis sumur gali dan air yang dikelola oleh Perusahaan Daerah Air Minum (PDAM) milik pemerintah Kota Bengkulu. Berdasarkan hasil pemantauan Analisa Sampel Air Lembaga Pusat Penelitian Lingkungan Hidup Universitas Bengkulu Mei 2010 disimpulkan bahwa dari total delapan kecamatan yang ada 
di Kota Bengkulu kondisi air sumur masyarakat tercemar ringan karena semua parameter yang diamati menunjukkan hasil di atas ambang baku mutu kualitas air.

Sedangkan air yang berasal dari Perusahaan Daerah Air Minum (PDAM) milik pemerintah Kota Bengkulu, diperoleh data bahwa satu diantara dua sumber air PDAM Kota Bengkulu yakni PDAM Surabaya (DAS Sungai Bengkulu) mempunyai sumber air yang kurang baik. Tingkat kekeruhan sumber air DAS Sungai Bengkulu mencapai 2000 NTU.

Rendahnya kualitas air DAS sungai Bengkulu sebagai sumber baku air PDAM Kota Bengkulu dapat disebabkan oleh beberapa faktor antara lain aktivitas masyarakat di sepanjang bantaran sungai seperti pembukaan areal hutan dan kebun, penambangan batu baru, perluasan pemukiman, limbah rumah tangga atau tingginya endapan sedimentasi akibat abrasi di kiri kanan DAS Bengkulu. Kondisi ini sangat membutuhkan perhatian khusus agar tidak semakin parah yang pada akhirnya berdampak negatif seperti banjir dan tercemarnya kualitas baku air konsumsi.

Keberadaan kelompok-kelompok usaha pengolahan tahu yang terdapat di Kota Bengkulu perlu didorong agar dapat terus eksis untuk memperkuat sektor ekonomi dalam menumbuhkan dan menunjang sektor industri yang mulai berkembang dan berbasis di kota-kota kecil. Sehingga secara tidak langsung keberadaan kelompok usaha seperti ini memainkan peran penting dalam mengisi dan menunjang pertumbuhan ekonomi nasional yang dimulai dari daerah dengan mempercepat pertumbuhan ekonomi masyarakat terutama masyarakat yang berada di kota Bengkulu.

Persoalan-persoalan penting seperti yang dihadapi beberapa kelompok usaha tahu untuk mendapatkan sumber air bersih yang mudah dan murah perlu segera dicarikan alternatif solusinya dengan merancang sistem penjernih air otomatis menggunakan sel surya sebagai sumber energi utama. Dengan rancangan sistem penjernih ini diharapkan dapat mempermudah pengusaha tahu memperoleh air bersih yang mudah dan murah baik dari sumber air sumur maupun sumber air PDAM atau dari sumber air manapun. Rancangan sistem penjernih juga dapat meningkatkan kualitas fisik, kimia dan biologi air yang nantinya secara tidak langsung akan meningkatkan kualitas dan kuantitas tahu yang dihasilkan.

\section{METODE PENGABDIAN}

Metode pendekatan yang dilakukan untuk mendukung realisasi program PKM adalah sebagai berikut:

Presentasi materi tentang peran teknologi pada proses penjernihan air untuk meningkatkan kualitas air digunakan dalam proses pembuatan tahu. Peningkatan kualitas air dilihat dari tiga aspek yaitu fisik, kimia dan biologi air. Standar kualitas air yang dijadikan acuan adalah Permenkes No.492/Menkes/per/IV/2010 tahun 2010 tentang Persyaratan Kualitas Air Minum. Materi presentasi juga diarahkan ke pembahasan tentang kelebihan model sistem penjernih yang dirancang dengan sumber energi utama berbasis teknologi sel surya yang merupakan teknologi dengan biaya murah (tanpa suplai listrik PLN) dan ramah lingkungan.

Selanjutnya metode pendekatan dilanjutkan dengan pelatihan perakitan sistem/ alat penjernih dimulai dari perakitan hardware (perangkat keras alat penjernih), perakitan software (program sistem pengendali), perakitan sistem kelistrikkan dan pengujian. 


\section{Perakitan Hardware}

Pada tahap ini dipraktekkan cara merakit alat penjernih dan sekaligus menjelaskan fungsi beberapa komponen penting penyusun perangkat keras alat penjernih, antara lain aki, panel surya, filter air, sensor $\mathrm{pH}$, sensor flow dan lampu ultraviolet (UV). Hal pokok yang menjadi sasaran penting dalam perakitan hardware adalah mitra memahami prinsip kerja komponen dan alat penjernih yang dirancang. Selanjutnya perakitan hardware meliputi perakitan rangka penempatan panel surya dan tabung filter dan penentuan komposisi media filter.

\section{Perakitan software}

Perakitan software sistem penjernih air meliputi perancangan rangkaian power supply, rangkaian kendali pengisian baterei dan rangkaian sistem kontrol lampu UV.

2.1. Perancangan Rangkaian Power Supply

Power supply berfungsi untuk menyalurkan arus dan tegangan ke seluruh rangkaian yang ada pada sistem. Rangkaian power supply ini terdiri dari dua keluaran yaitu 5 volt dan 12 volt, keluaran 5 volt digunakan untuk menyuplai rangkaian mikro (arduino) dan tegangan 12 volt digunakan untuk menyuplai driver relay. Gambar 1. merupakan rangkaian power supply yang digunakan pada rancangan sistem. Sumber tegangan 12 volt DC didapat dari baterai yang telah diisi dengan panel surya. Tegangan 12 volt DC diratakan oleh kapasitor 2200uF. Regulator tegangan 5 volt digunakan agar keluaran tetap stabil di 5 volt. LED hanya berfungsi sebagai indikator saat power supply dinyalakan.

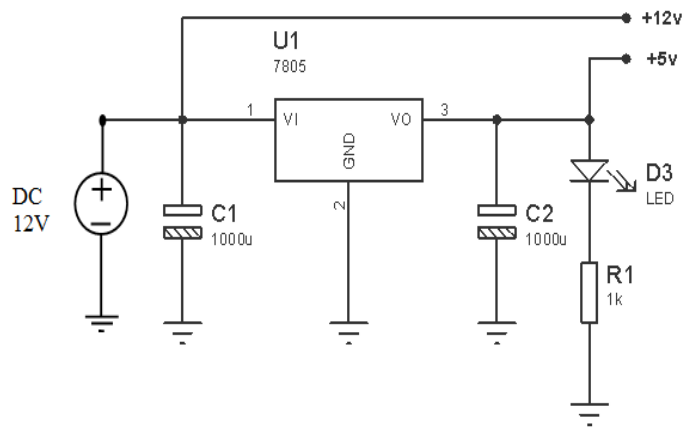

Gambar 1. Rangkaian Power Supply

\subsection{Perancangan Rangkaian Pengisian Baterai}

Rangkaian ini berguna untuk memberikan indikator baterai penuh saat pengisian. Rangkaian pengisian baterei yang digunakan seperti gambar 2 .

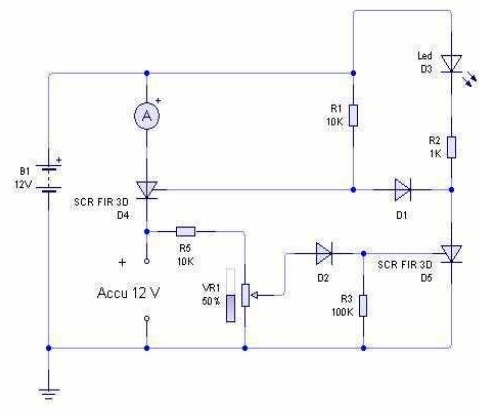

Gambar 2. Rangkaian Pengisian 
Prinsip kerja dari rangkaian gambar 2. yakni tegangan sumber 12 volt mengalir melalui Ampere meter dan kemudian ke SCR. SCR akan mengatur tegangan sumber 12 volt dari panel surya menuju baterai. Bila baterai telah penuh maka SCR akan mengalirkan tegangan ke D1 sehingga tegangan + akan melalui kaki katoda led indikator sehingga led menyala. Terdapat VR sebagai tahanan pengatur tegangan yang akan masuk ke baterai.

2.3. Perancangan Rangkaian Sistem Kontrol Lampu UV

Rancangan kelistrikan kontrol lampu UV yang diterapkan pada alat penjernih air sementara masih menggunakan sumber listrik dari PLN. Kedepan sumber listrik yang digunakan berasal dari panel surya. Listrik yang dihasilkan pada saat di bawah sinar matahari dialirkan ke regulator yang bertindak sebagai pengontrol pengisian listrik ke baterai. Arus listrik dari baterai disalurkan ke mikrokontroller sebagai pengontrol kinerja lampu UV dan ke inverter. Listrik yang keluar dari inverter digunakan untuk kebutuhan tegangan 220 volt pada lampu UV. Listrik yang masuk ke relai sebagai saklar digunakan untuk menyuplai tegangan pada lampu UV.

\section{Perancangan Sistem Kelistrikan}

Pada tahap ini dipraktekkan cara menempatkan sistem kelistrikan dalam rancangan hardware dan software alat penjernih. Listrik yang dihasilkan pada saat di bawah sinar matahari dialirkan ke regulator yang bertindak sebagai pengontrol pengisian listrik ke baterai. Listrik yang tersimpan pada baterai bertegangan 12 volt DC inilah yang digunakan untuk menjalankan semua perangkat elektronik pada sistem penjernih. Arus listrik dari baterai disalurkan ke mikrokontroller sebagai pengontrol kinerja alat, termasuk inverter. Listrik yang keluar dari inverter digunakan untuk kebutuhan tegangan 220 volt untuk mensuplai tegangan pada lampu UV atau komponen lain yang membutuhkan suplai listrik AC. Listrik yang masuk ke relai sebagai saklar digunakan untuk menyuplai tegangan pada lampu UV. Relai sebagai saklar dikontrol pengaktifannya oleh mikrokontroller dengan mengalirkan tegangan 5 volt dc pada kaki basis teransistor yang selanjutnya mengaktifkan kerja dari relai.

\section{Pengujian}

Pengujian dilakukan masing-masing terhadap blok sistem. Hal ini dilakukan untuk melihat sejauh mana blok sistem yang telah dirancang dapat bekerja sesuai fungsi dan perannya. Berikut metode pengujian untuk masing-masing blok sistem :

4.1. Pengujian Filter dan Penyinaran UV

Pengujian filter dan UV dilakukan untuk melihat apakah blok sistem ini sudah bekerja sesuai fungsinya atau tidak. Pengujian dilakukan dengan mengambil sampel air sebelum difilter dan air setelah difilter saat diberi penyinaran lampu UV. Air sampel sebelum difilter dibandingkan secara fisik dengan air setelah difilter dan selanjutnya diuji di laboratorium untuk melihat kinerja sistem UV. Bila terjadi perubahan pada kualitas fisik dan biologi air sampel berarti filter dan sistem UV bekerja sesuai fungsinya.

\subsection{Pengujian Sensor $\mathrm{pH}$}

Pengujian sensor $\mathrm{pH}$ dilakukan untuk melihat kinerja dari sensor $\mathrm{pH}$. Penggunaan sensor $\mathrm{pH}$ pada sistem penjernih air bertujuan sebagai deteksi awal kualitas kimia air yang hasil datanya realtime sebelum dilakukan pengujian laboratorium. Sensor $\mathrm{pH}$ diletakkan setelah keluaran lampu UV dan disambungkan ke mikro. Mikro akan membaca besar $\mathrm{pH}$ pada air dan mengatur tegangan yang masuk ke solenoid valve yang berada sebelum lampu UV. Solenoid valve ini berfungsi untuk memutuskan aliran air bila air memiliki pH yang rendah. Pengujian dilakukan dengan cara membandingkan hasil pembacaan menggunakan sensor $\mathrm{pH}$ dan pembacaan $\mathrm{pH}$ menggunakan kertas lakmus dan uji laboratorium. Bila 
deteksi sensor $\mathrm{pH}$ mendekati pembacaan $\mathrm{pH}$ pada kertas lakmus dan hasil uji laboratorium berarti sensor $\mathrm{pH}$ bekerja sesuai dengan fungsinya.

\subsection{Pengujian Panel Surya}

Pengujian panel surya bertujuan untuk mengetahui berapa besar kebutuhan energi sistem penjernih air dapat disuplai dari panel surya. Pengujian panel surya dimulai dengan melakukan pengisian dan pengosongan aki. Pengisian dan pengosongan aki menggunakan panel surya dilakukan untuk mengetahui lama pengisian dan pengosongan aki pada sistem. Pengujian dilakukan dengan cara menghidupkan keseluruhan sistem dan mengukur tegangan yang ada pada aki. Waktu yang diperlukan untuk mengosongkan aki akan dicatat. Setelah aki kosong selanjutnya pengujian dilanjutkan dengan pengisian aki. Pengujian pengisian aki dilakukan dengan mengukur tegangan sebelum aki diisi dan tegangan pada saat aki penuh. Seperti pada saat pengujian pengosongan aki, waktu yang diperlukan untuk mengisi aki juga akan dicatat. Bila panel surya mampu mensuplai kebutuhan energi sistem yang dirancang selama 24 jam berarti panel surya bekerja sesuai dengan fungsinya.

Selanjutnya untuk melihat kinerja hasil rancangan sistem penjernih air secara keseluruhan dilakukan pengujian akhir hasil laboratorium terhadap parameter kualitas air yang dihasilkan.

\section{HASIL DAN PEMBAHASAN}

Hasil yang dicapai dari beberapa tahapan metode pelaksanaan dalam kegiatan pengabdian, dapat dijelaskan beberapa hal sebagai berikut:

\section{Perakitan Hardware}

Pada tahapan ini dilakukan perakitan beberapa komponen penting penyusun modul sistem penjernih. Perakitan alat penjernih air yang digunakan untuk meningkatkan kualitas produk tahu pada kelompok usaha tahu yang menjadi mitra dalam kegiatan ini secara konsep memiliki kesamaan, yaitu melakukan pengolahan terhadap air yang digunakan sebagai komponen vital dalam proses pembuatan tahu. Hal ini dilakukan dengan cara melakukan pengolahan (treatment) terhadap beberapa parameter kualitas air, yaitu : fisika, biologi dan kimia air. Treatment fisika air dilakukan dengan menggunakan beberapa rangkaian filter, selanjutnya biologi air dengan menggunakan modul ultraviolet, sedangkan kimia air menggunakan injeksi larutan kimia yang dapat memperbaiki kualitas $\mathrm{pH}$ air. Namun secara tidak langsung treatment fisika air berpengaruh terhadap kualitas biologi dan kimia air, begitu juga sebaliknya.

Selanjutnya untuk mengetahui berapa banyak filter yang digunakan dan komposisi pada masing-masing filter, maka dilakukan pengujian kombinasi filter untuk mengetahui berapa kekuatan debit air untuk mensuplai kebutuhan air pada proses pembuatan tahu. Dari pengujian kombinasi filter diperoleh data sebagai berikut:

Tabel 1. Hasil Pengujian Debit Air

\begin{tabular}{cccc}
\hline No. & Banyak Filter & Debit (L/menit) & Waktu Pengisian 250 Liter Air \\
\hline 1 & 1 & 19,74 & 12,66 menit \\
2 & 2 & 19,42 & 12,87 menit \\
3 & 3 & 19,1 & 13,00 menit \\
4 & 4 & 18,8 & 13,30 menit \\
\hline
\end{tabular}




\section{6}

Dharma Raflesia Unib Tahun XVI, Nomor 1 Juni 2018
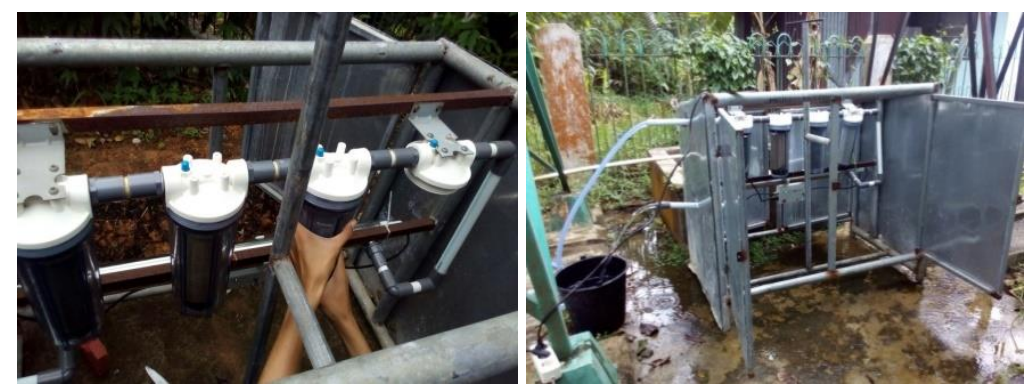

Gambar 3. Pengujian Kombinasi Filter dan Pengukuran Debit Air

Dari tabel diperoleh bahwa variasi jumlah filter (mulai dari 1 filter hingga 4 filter) tidak cukup signifikan berpengaruh terhadap jumlah debit dan waktu yang dibutuhkan untuk mensuplai kebutuhan air. Dengan dasar ini, maka rancangan jumlah filter yang digunakan untuk melakukan treatment fisika air sebanyak empat buah, dengan komposisi sebagai berikut: filter pertama berisi pasir aktif, filter kedua berisi ziolite, filter ketiga berisi karbon dan filter keempat berisi dewater. Keempat kandungan filter ini memiliki peran yang berbeda-beda untuk memperbaiki kualitas fisika, biologi dan kimia air. Berikut skema gambar rancangan modul penjernih air yang diaplikasikan pada kelompok usaha tahu DWI menyesuaikan dengan kondisi yang ada di lapangan.

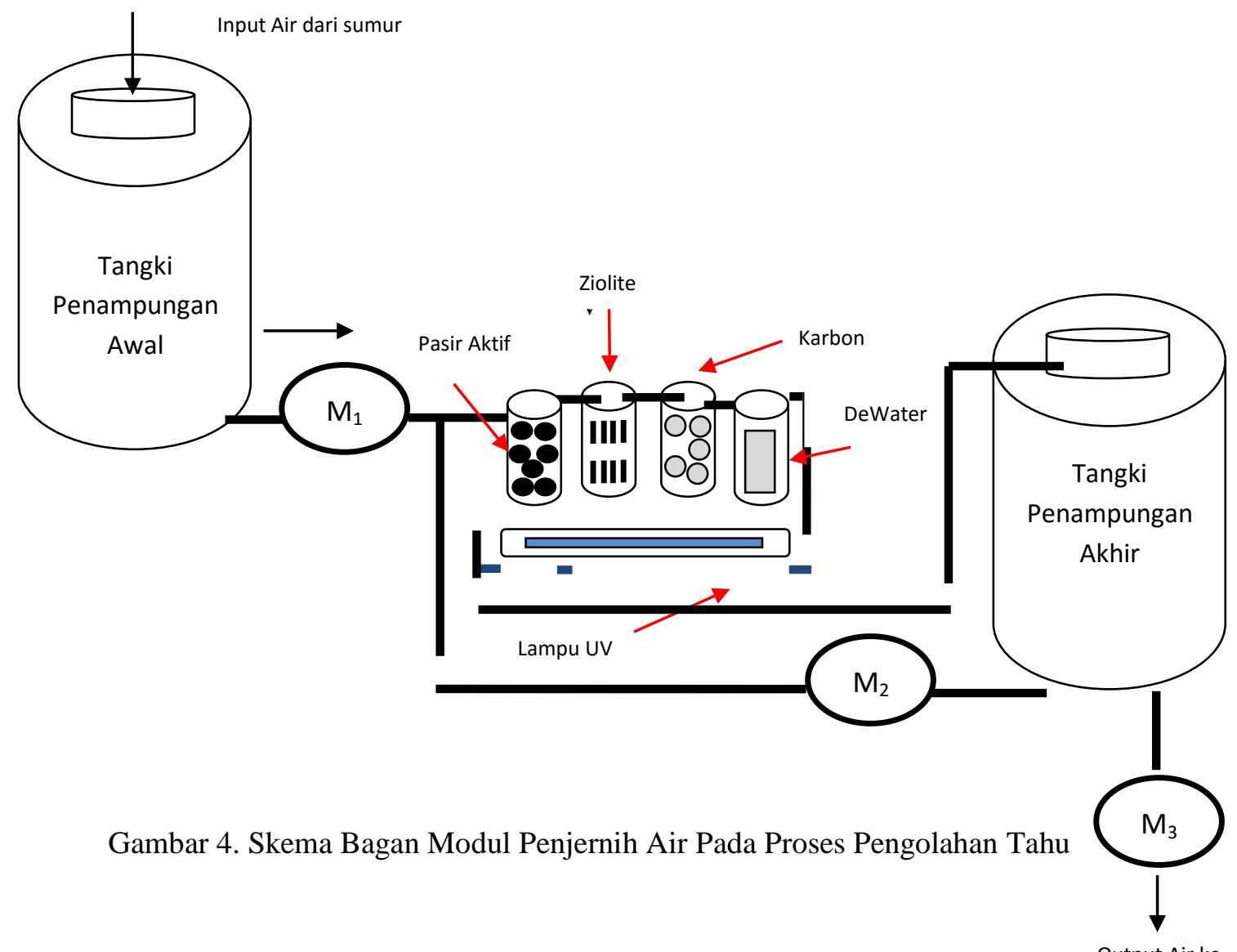


Dari gambar 4 dapat dijelaskan bahwa air yang akan digunakan untuk pembuatan tahu berasal dari sumur bor lalu ditampung dalam tangki penampungan awal untuk ditretment. Pada saat motor pompa pertama (M1) dalam kondisi normally open (NO) maka pompa M1 mendorong air dari tangki penampungan awal menuju tangki penampungan akhir melewati modul filter dan modul ultraviolet (uv), untuk menjalani proses treatment fisika dan biologi air. Pada posisi ini motor pompa kedua (M2) dan motor pompa ketiga (M3) dalam kondisi normally close (NC).

Selanjutnya sensor TDS dan sensor $\mathrm{pH}$ yang diletakkan di dalam tangki penampungan akhir mendeteksi kualitas air yang ada dalam tangki penampungan akhir. Jika sensor TDS dan sensor $\mathrm{pH}$ membaca kualitas air tidak sesuai dengan nilai set point normal sensor TDS dan sensor pH, maka motor M1 dan M3 akan berada pada kondisi NC, sedangkan motor M2 dalam kondisi NO. Pada kondisi ini kualitas air yang belum normal dalam tangki penampungan akhir dihisap oleh motor M2 untuk dialirkan kembali menuju modul filter dan modul uv menjalani treatment kedua. Hal ini terus berulang sampai saat sensor TDS dan sensor pH membaca nilai deteksi air pada tangki penampungan akhir sesuai dengan nilai set point kondisi normal.

Bila sensor TDS dan sensor $\mathrm{pH}$ air pada tangki penampungan akhir mendeteksi air pada posisi normal maka motor M1 dan M2 berada pada kondisi NC, sedangkan motor M3 pada kondisi NO. Pada kondisi ini, motor M3 akan mendistribusikan air yang telah ditreatment untuk selanjutnya digunakan dalam proses pembuatan tahu.

\section{Perakitan Software}

Perakitan software yang telah dilakukan dalam kegiatan pengabdian ini meliputi pekerjaan merancang sistem kendali fisika dan kimia air menggunakan sensor kekeruhan (TDS) dan sensor pH. Perancangan sistem kendali fisika dan kimia air meliputi kegiatan pembuatan bahasa program kendali, kalibrasi sensor dan pengujian performance sensor. Bahasa program yang digunakan untuk pembacaan sensor menggunakan bahasa $\mathrm{C}$, sedangkan kalibrasi sensor bisa dilakukan dengan beberapa cara antara lain mengukur nilai deteksi sensor yang dihasilkan terhadap sampel air yang digunakan. Selanjutnya hasil pengukuran deteksi sensor dibandingkan dengan hasil pengukuran dari alat ukur TDS meter dan $\mathrm{pH}$ meter digunakan untuk mengukur sampel air yang sama. Bila harga deteksi sensor mendekati pembacaan alat ukur, maka proses kalibrasi selesai dilakukan atau bisa menggunakan cairan yang nilai $\mathrm{pH}$ dan TDS nya sudah ditentukan, lalu memastikan nilai sensor sesuai dengan nilai tersebut dengan memutar potensio di modul sensor.

Setelah pembacaan dan kalibrasi sensor selesai dilakukan, maka tahapan berikutnya melakukan sistem koordinasi dengan plant yang melakukan aksi. Dalam hal ini koordinasi relay terhadap motor pompa. Apabila sensor mendeteksi nilai $\mathrm{pH}$ atau nilai NTU (besaran harga TDS) tidak sesuai dengan set point awal maka sistem relay bekerja, memerintahkan pompa motor untuk aktif.

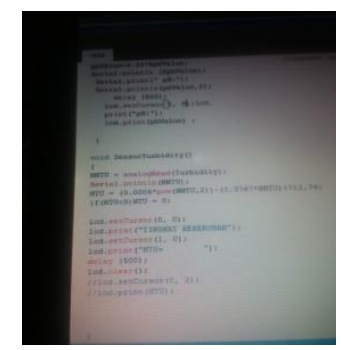

Gambar 5. (a). Bahasa Program Sis
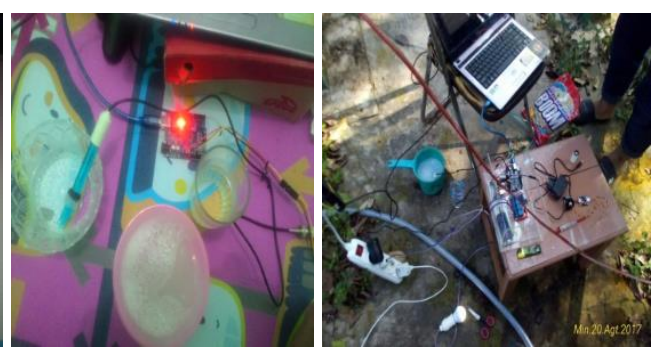

Koordinasi Relay 
Setelah tahapan perancangan hardware dan perancangan software selesai, tahapan yang paling penting adalah tahapan implementasi dari rancangan modul sistem yang dibuat secara keseluruhan terhadap proses pembuatan tahu yang ada di kelompok usaha tahu yang terdapat di kota Bengkulu. Dari hasil unjuk kerja modul filter, modul ultraviolet, deteksi sensor TDS dan sensor $\mathrm{pH}$ terhadap kualitas air yang terbaca di LCD dapat diketahui hasil pembacaan (display) deteksi sensor TDS dan sensor $\mathrm{pH}$ terhadap kondisi kualitas air sebelum dan sesudah menggunakan modul penjernih sebagai berikut:
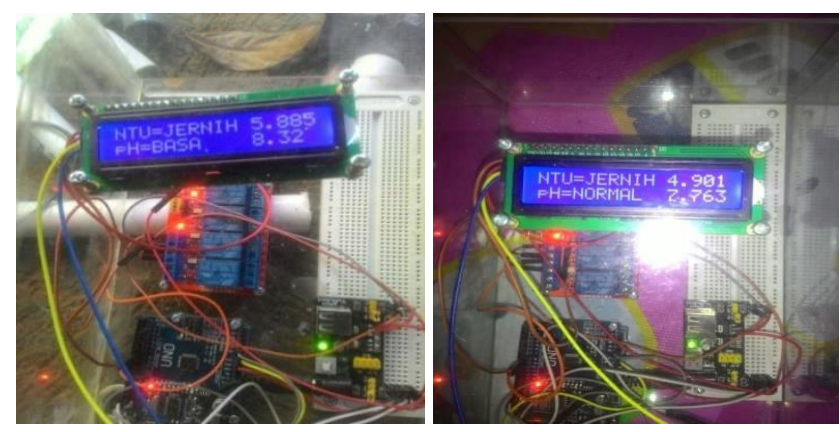

Gambar 6. Pembacaan LCD Modul Penjernih pada Mitra, (a). Pembacaan sebelum ditreatment (b). Pembacaan sesudah di-treatment

Tabel 2. Pembacaan LCD Modul Penjernih Pada Air Yang Digunakan Mitra

\begin{tabular}{ccc}
\hline Kondisi & Nilai NTU & Nilai pH \\
\hline Sebelum & 5,885 & 8,320 \\
Sesudah & 4,901 & 7,763 \\
\hline
\end{tabular}

Untuk mengetahui keberhasilan performance modul yang dirancang terhadap peningkatan kualitas tahu yang dihasilkan dilakukan uji laboratorium terhadap hasil treatment air yang telah dilakukan. Pengambilan data sampel air dilakukan pada hari Jumat tanggal 25 Agustus 2017. Pengujian laboratorium juga membandingkan kondisi kualitas air yang digunakan sebelum dilakukan proses treatment dan setelah dilakukan proses treatment.

Tabel 3. Hasil Pengujian Laboratorium Terhadap Sampel Air Yang Digunakan

\begin{tabular}{lcc}
\hline \multicolumn{1}{c}{ Parameter } & Sebelum Treatment & Setelah Treatment \\
\hline TSS (mg/L) & 100,5 & 16,5 \\
DHL (daya hantar listrik) & 459 & 469 \\
pH & 7,5 & 7,4 \\
Coli Total $(/ 100 \mathrm{~mL})$ & 551 & 28 \\
\hline
\end{tabular}

Dari hasil pengujian laboratorium diperoleh perubahan hasil yang cukup signifikan terjadi pada treatmen fisika air (TSS) dan biologi air (Coli Total). Pemasangan rangkaian filter, penempatan sensor pendeteksi kualitas fisik air, sistem kendali UV dan motor pengolah air merupakan bentuk treatmen fisik dan biologi air yang diterjemahkan dalam rancangan modul, sedangkan untuk kimia air, perubahan hasil yang terjadi tidak cukup signifikan, baik pada kemampuan daya hantar listrik maupun pada kandungan $\mathrm{pH}$ air. Hal ini disebabkan karena treatmen kimia pada rancangan modul belum dilakukan secara 
optimal. Treatmen kimia pada air (misal dengan melakukan injeksi larutan zat kimia) dikhawatirkan akan mempengaruhi kualitas tahu yang dihasilkan menjadi lebih buruk.

Berikutnya juga dilakukan uji organoleptik terhadap kualitas tahu yang dihasilkan sebelum dan sesudah dilakukan proses treatmen. Uji laboratorium organoleptik dilakukan terhadap parameter warna, aroma, tekstur dan kesukaan (overall) tahu sebelum dan sesudah ditreatmen menggunakan modul penjernih air yang dirancang baik tahu putih (yang belum digoreng) maupun tahu yang sudah digoreng. Uji organoleptik dilakukan terhadap responden yang tidak terlatih sebanyak 20 orang. Responden diminta untuk mengisi lembar kuisioner memberikan penilaian hasil pengamatan indera terhadap sampel tahu yang diberikan tanpa ada pemberitahuan awal sampel tahu mana yang belum atau sudah ditreatmen. Contoh lembar kuisioner dan hasil pengolahan data sebagai berikut :

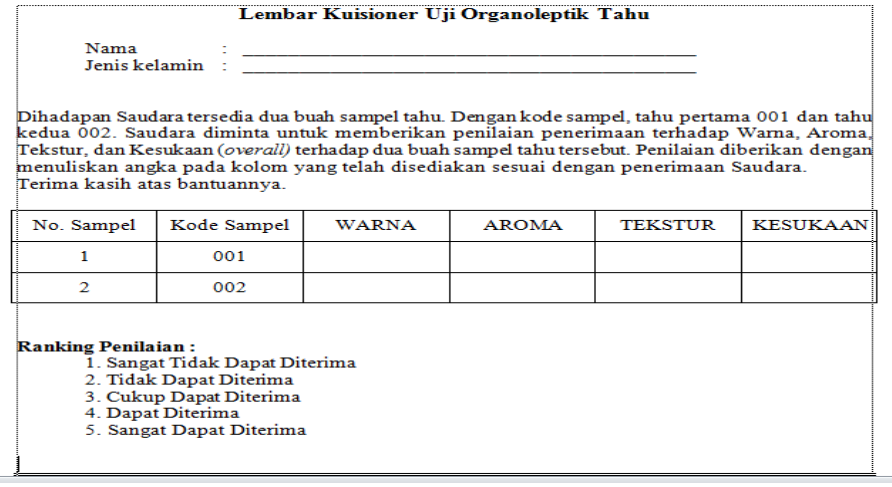

Gambar 7. Contoh Lembar Kuisioner

\section{KESIMPULAN DAN SARAN}

\section{Kesimpulan}

1. Pembacaan LCD dari penggunaan modul penjernih yang dirancang, dapat diketahui bahwa deteksi sensor TDS dan sensor $\mathrm{pH}$ terhadap kualitas air sebelum dilakukan proses penjernihan diperoleh nilai NTU sebesar 5,885 dan sensor $\mathrm{pH}$ sebesar 8,32, sedangkan sesudah dilakukan proses penjernihan diperoleh nilai NTU sebesar 4,901 dan sensor $\mathrm{pH}$ sebesar 7,763.

2. Hasil pengujian laboratorium terhadap sampel air yang digunakan dalam proses pembuatan tahu, sebelum dilakukan proses penjernihan diperoleh nilai parameter TSS sebesar 100,5 mg/L, DHL sebesar 459 msiemen, Coli Total sebesar 551/100ml, sedangkan setelah dilakukan proses penjernihan diperoleh nilai parameter TSS sebesar 16,5 mg/L, DHL sebesar 469 msiemen, Coli Total sebesar 28/100mL.

3. Hasil pengujian organoleptik terhadap sampel tahu yang dihasilkan baik sebelum digoreng maupun setelah digoreng secara umum terbukti mengalami perubahan yang cukup signifikan dari beberapa parameter pengujian (warna, aroma, tekstur dan kesukaan).

4. Hasil wawancara dengan pemilik usaha tahu (mitra) dan pengamatan langsung di lapangan, dapat disimpulkan bahwa ketahanan tahu menggunakan air sebelum dilakukan proses penjernihan berkisar antara 1 sampai 1,5 hari, sedangkan ketahanan tahu menggunakan air sesudah dilakukan proses penjernihan berkisar antara 2 sampai 3 hari. 


\section{Saran}

Agar rancangan modul sistem penjernih ini dapat digunakan kapan dan dimana saja pada kelompok usaha industri tahu yang jauh dari jaringan listrik PLN, maka penggunaan teknologi hybrid termasuk panel surya dan kincir angin dapat menjadi alternatif solusi mengatasi masalah suplai energi.

\section{DAFTAR PUSTAKA}

Amri, K, Priyadi I, dan Hadi F, 2014, Perancangan Sistem Penjernihan Air Otomatis Menggunakan Sel Surya Sebagai Sumber Energi, Laporan Penelitian, Universitas Bengkulu: Bengkulu.

Hadi, F, Priyadi I, dan Efendi Z, 2015, IbM: Kelompok Usaha Pisang Salai Dalam Upaya Peningkatan Kualitas Pisang Salai di Kota Curup Propinsi Bengkulu, Laporan Pengabdian, Universitas Bengkulu: Bengkulu.

Nuraida, 1985, Analisis Kebutuhan Air Pada Industri Pengolahan Tahu dan Kedelai, dalam Lisnasari, S.F., 1995, Pemanfaatan Gulma Air (Aquatic Weeds) Sebagai Upaya Pengolahan Limbah Cair Industri Pembuatan Tahu, Thesis Master Program Sarjana USU: Medan.

Rahmawati, 2013, Teknologi Proses Pengolahan Tahu dan Pemanfaatan Limbahnya, Fakultas Teknik UNY: Yogyakarta.

Rohim, M, Destiarti L, dan Zaharah, T.A, 2015, Uji Organoleptis Tahu Tersalut Kitosan (Tahu-Edible Coating Kitosan), JKK, 4(3):54-58. 